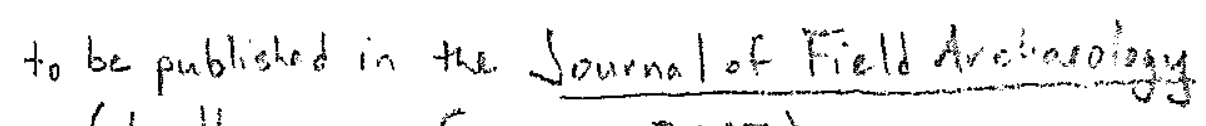

$$
\begin{aligned}
& \text { (shanld ogpar Summer } 2007 \text { ) }
\end{aligned}
$$

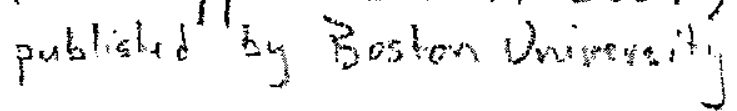

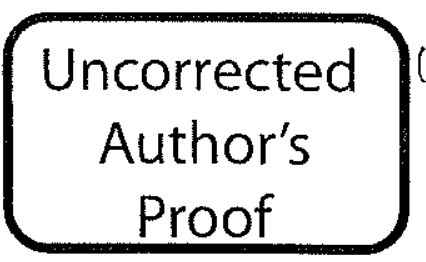

\title{
Rural Settlement and Soil Erosion from the Late Roman Period through the Medieval Islamic Period in the Lower Alentejo of Portugal
}

\author{
James L. Boone
}

\section{F. Scott Worman \\ University of New Mexico Albuquerque, New Mexico}

This article presents the results of a site survey of Late Roman period and Medieval Islamic period rural settlements in the Lower Alentejo of southern Portugal, and of geoarchaeological investigations that evaluate the role of human activity and environmental change in the pattern of settlement growth, decline, and abandonment documented by the survey. The survey revealed that some time after the dissolution of Roman control of Iberia in the 5th century A.D., small hamlets and villages began to appear in the study area. Over the next 500 years, and particularly following the Muslim invasion of A.D. 711 , settlement density increased sixfold over what it had been during the Roman period. The most salient transformations in settlement patterning and material culture that occurred during this period, however, coincided with the consolidation of the Ummayad Caliphate in Córdoba in the mid-10th century, rather than the Arab and Berber invasion of A.D. 711. Subsequently, during the mid-12th century, the majority of rural villages were abandoned, nearly a century before the Christian Reconquista in A.D. 1238. The region remained largely depopulated until the mid-late 1400 s, and settlement density in the region was neper again as high as it was during the later Medieval Yslamic period. Geoarchaeological evidence of widespread erosion and soil loss suggests that overuse of the land may have been a factor in the abandonment.

\section{Introduction}

In this article, we present the results of archaeological and geoarchaeological research concerning land-use and settlement in the Lower Alentejo of southern Portugal from the Roman period through the Medieval and early Modern periods. We first discuss the results of a site survey and excavations of Late Roman period and Medieval Islamic period rural settlements in the vicinity of Mértola. We then present the results of ongoing geoarchaeological investigations designed to evaluate the roles of environmental change and anthropogenic factors in the pattern of settlement growth, decline, and abandonment documented by the survey.

The site survey revealed that soon after the dissolution of Roman control of Iberia in the 5 th century A.D., Roman villas and farmsteads were abandoned and small hamlets and villages appeared in new locations in the study area.
Over the next 500 years, and particularly following the Muslim invasion of A.D. 711, settiement density increased sixfold over what it had been during the Roman period. Subsequently, during the mid-12th century A.D., the majority of rural villages were abandoned. The rural landscape remained largely depopulated until the mid-1400s, when the region was reoccupied by farmers and herders, probably from regions to the north. Rural site density and the total settlement area in the Christian Medieval and Modern periods never grew to more than a third of what they had been during the Medieval Islamic period. The preliminary results of these investigations suggest that landscape change caused by human activities was a significant factor in the abandonment.

\section{Environmental Background}

The climate pattern in the study area is Mediterranean, with hot, dry summers and wet winters with infrequent 
freezing temperatures. Rainfall averages $550 \mathrm{~mm}$, most of which falls between October and April (based on figures for Beja from 1931-1960) (Amorim Ferreira 1970: 118). The maximum difference in relief within the survey area is about $100 \mathrm{~m}$, although most of the land lies between 150 and 200 masl. Within this range, however, the land surface is hilly and uneven, and average slopes are between $9 \%$ and 25\% (Carta da Capacidade de Uso de Solo 1962; Santos 1987: 42).

Traditional agricultural production follows a widespread pattern, termed the "Mediterranean agrosystem" by Butzer (1996: 142), which includes extensive cereal agriculture, maintenance of large flocks of sheep and goats and more limited production of olives and grapes. The permanent watercourse in the region, the Guadiana River, is deeply entrenched such that large-scale irrigation is impossible using traditional technologies. The rest of the study area is drained by deeply cut ribeiras, or creeks, that cease to flow during the summer months. Hence, agriculture and pastoralism are dependent on rainfall except for small, scattered walled gardens that can be watered by norias, or wells with water wheels. Soils throughout the study area are relatively thin, rocky lithosols derived from underlying flysch bedrock (folded and uplifted meta-sedimentary rock originating from marine deposits). Soil fertility is uniformly poor, and $95 \%$ of the survey area is currently classified under the poorest soil category (Carta de Capacidade de Uso do Solo 1962) due to a combination of high slope and thin, skeletal soils although historically cereal crops have been routinely planted. Fallow periods currently vary from four to seven years and combinations of animal manure and chemical fertilizer are used to boost soil fertility.

\section{Settlement Archaeology in the Lower Alentejo}

In 1992, our survey covered an $8 \times 8 \mathrm{~km}$ square (FIGs. I-s) (Boone 1994, 2002), with survey transects $50 \mathrm{~m}$ apart. Soils are very thin there, and vegetation cover in the summer is minimal after the harvested fields have been subjected to sheep and goat grazing. Roman and Medieval sites were easily discernible on the surface as scatters of building stone and broken rooftiles and pottery. In many cases, low oval mounds of stone representing collapsed structures were visible on the surface. Our survey methods were not designed to detect the small lithic and pottery scatters of prehistoric sites. The only chipped stone artifact found during the survey was a gunflint. About 20 light scatters of pottery and ground stone artifacts probably dating to the Chalcolithic through the Iron Age Periods were identified, but will not be discussed here.

Our survey identified eight sites having Roman or Late Roman remains (FIG. 2). An additional 17 sites were as- signed to what we will refer to as a Transitional period, dating from the end of the Late Roman period through the early Islamic period (A.D. 600-950, explained in more detail below). 157 sites were assigned to the later Islamic period (FIG. 3), representing a sixfold increase in settlement density over the Roman and Transitional periods. Settlement densities were greater during the Islamic period than before or after, with combined settlement area on the order of three times what it would be in the Modern period. The transition from the Late Roman period to the Medieval Islanic period in the Lower Alentejo of Portugal is characterized by a radical reorganization of the rural settlement system from an evenly spaced pattern of modest villas and farmsteads to a dense distribution of field houses, hamlets, and hilltop villages.

\section{Roman Settlement}

Artifacts diagnostic of the Roman and Late Roman periods are predominantly terra sigillatas, Roman common wares, and tegulae, or flat, Roman-style rooftiles. On the basis of surface materials and location, the sites containing Roman artifacts can be divided into four general categories: fortified villas, unfortified hilltop sites, unfortified later villas, and Transitional period sites.

The site of Papa Leite, a fortified villa, is one of 20 small, fortified early Roman sites recorded in the Lower Alentejo (Alarcăo 1988: 109-110). Another such site, Manuel Galo, is located about a kilometer south of the survey area. These fortified villas (sometimes referred to as castellac; sing. castellum) were founded in the lst century B.C., apparently as part of an official colonization effort sponsored by Pompey or Julius Caesar, the goal of which was to protect routes over which copper and silver were carried from mines located on the western margins of the Pyrite Belt to the Guadiana River port of Mértola. The fortifications appear to have fallen out of use by the end of the lst century A.D. at the latest.

The interpretation of four unfortified hilltop sites containing small amounts of Early Roman materials is problematic. Four of these sites contain Campanian wares and early terra sigillatas and may even predate the aforementioned fortified villas (and extend back to the 2nd century B.C.). Coarse, thick, hand-formed common wares made of local clay, resembling wares found in Iron Age sites, also occur on the surfaces of these sites. There is fairly abundant building stone present, although much of it appears to have been collected on the surface and in stream beds; quarried stone is more typical of Roman period and Medieval Islamic period construction. At some of the sites, burned clay was recovered, possibly indicating wattle-anddaub construction. Tegulae and other rooftiles were ab- 

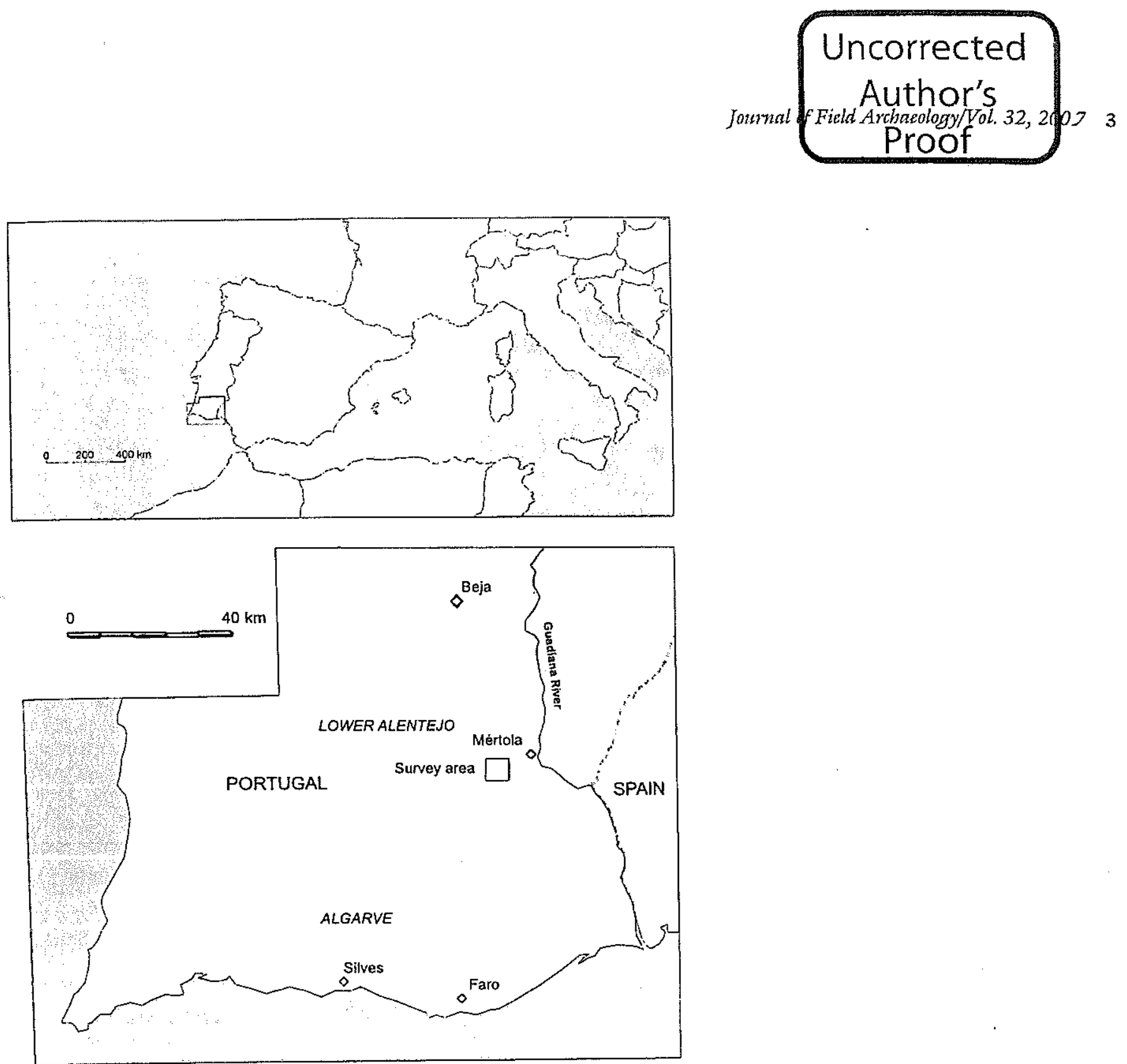

Figure 1. Maps showing the location of the study area in southern Portugal.

sent, suggesting that structures at these sites had thatched roofs. Our current and tentative interpretation of these sites is that they were occupied by indigenous Iron Age peoples engaged in trade and/or raiding relationships with the Roman colonists. Like the fortified villas, these sites were most likely abandoned by the lst century A.D. at the very latest.

Three unfortified later Roman villas, or farmstead sites, were recorded in valley floor locations, including one siruated adjacent to Papa Leite. Terra sigillatas found on the surface of these sites date from the 1 st to as late as the 5 th centuries A.D. Quarried building stone and tegulae are also abundant. These sites contain no Medieval Islamic materials and were clearly abandoned by the 6th century A.D., and probably earlier. These villa or farmstead sites are quite modest in extent compared to the large villas found to the north in the vicinity of Beja and Vidigueira (for example, at Pisóes, Sáo Cucufates, and Monte Cigonha) or to the south in the Algarve (e.g., at Cerro da Vila).

With the withdrawal of Roman military protection in the first decade or two of the 5 th century A.D., the small villas and Roman farmsteads in the survey area were abandoned and never reoccupied. Although central places like Mértola and a few religious sites in the region continued to be occupied (Lopes 2003), there is a period of archaeological invisibility of nural sites that lasts until the 7th century A.D. Excavations at the Paleochristian basilica of Rossio do Carmo in Mértola (Macias 1993; McMillan and Boone 1999) revealed over 50 grave stones with epitaphs that reflect a continuing but declining population from the 5 th 


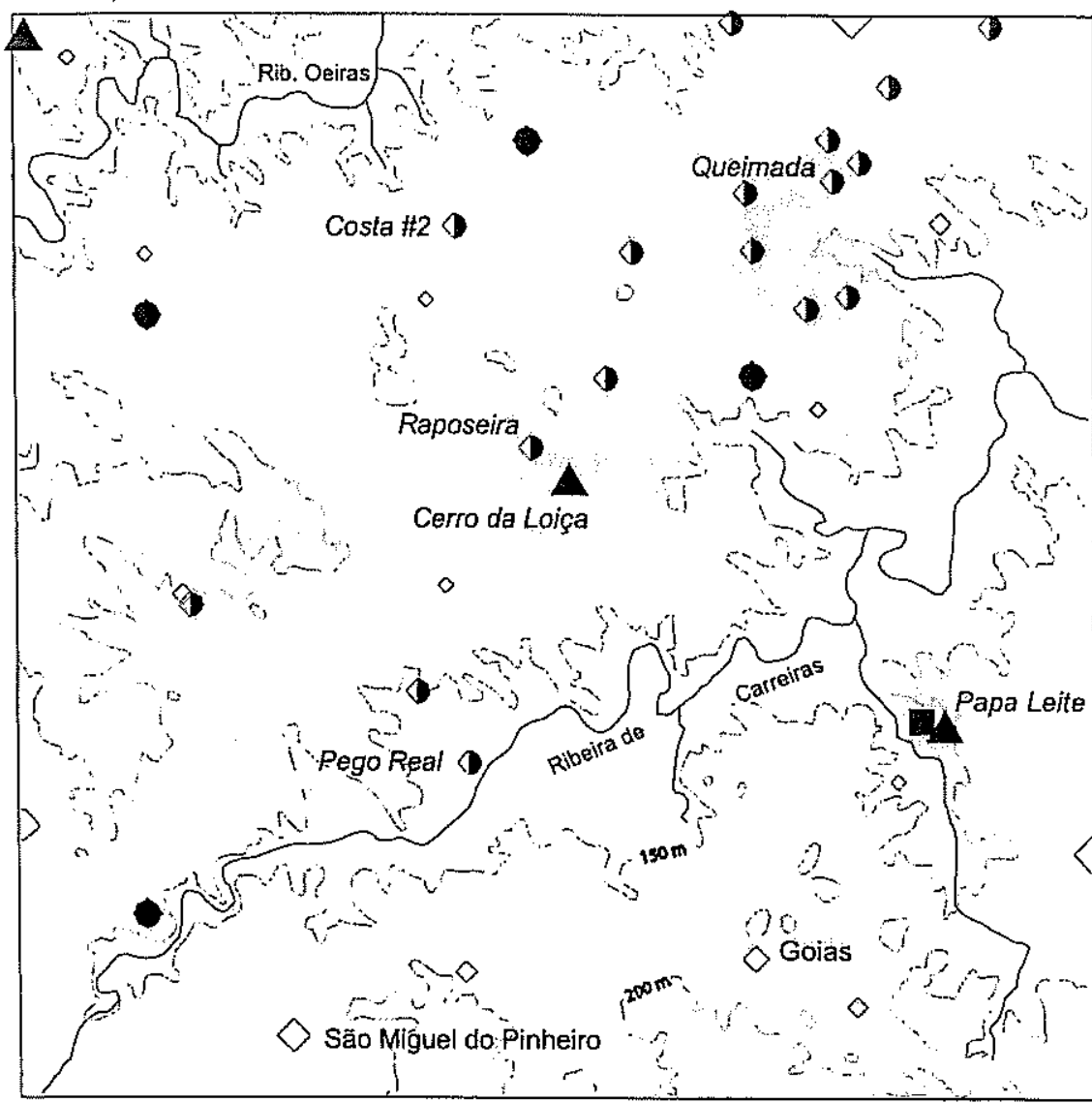

Roman castellum

Roman period hilltop site

Roman villa or farmstead

Transitional period site

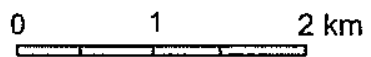

Figure 2. Map of the $8 \times 8 \mathrm{~km}$ survey area showing the location of Roman, Transitional, and Modern (open circles) setrlements. Sites in italics are those discussed in the text. Gray areas denote higher quality soils (pardos mediterranicos).

century through the beginning of the 8th century A.D. These epitaphs record the burial of members of HispanoRoman elite families (honestiores), religious devotees (presbyters, monks, and nuns), who were themselves often drawn from such families, as well as a few foreigners of eastern Mediterranean origin - probably merchants and traders - from as far away as Libya. Of the 40 stones that included legible dates of death, $6(15 \%)$ were from the late 5 th century, 24 $(60 \%)$ were from the first half of the 6 th century (A.D. 500-550), 7 (17.5\%) were from A.D. 550-600, 2 were from A.D. 601-700, and a single stone was dated A.D. 706, five years before the Muslim invasion.

\section{Transitional Settlements}

Seventeen habitation sites from the Late Roman and early Medieval Islamic periods are termed "transitional" because they lack material that is distinctive of the earlier Roman period or the succeeding later Medieval Islamic period (FIG. 2). The flat square Roman tegulae are absent, and roofs were constructed using only the tapered halfcylindrical imbrex tiles, many of which have a distinctive thumb-impressed design motif along the lateral edges (FIG. 6) that is never found in sites dating to the later Medieval Islamic period (A.D. 950-1238), such as Alcaria Longa. In 1993, excavations at the rooftile kiln site of Pego Real (FIG. 2) confirmed that this design dates to the period between about A.D. 600 to 950 (TABLE I). This allows us to distinguish Transitional and early Medieval Islamic period sites from later Medieval Islamic period sites to a certain extent, although we do not know precisely when 


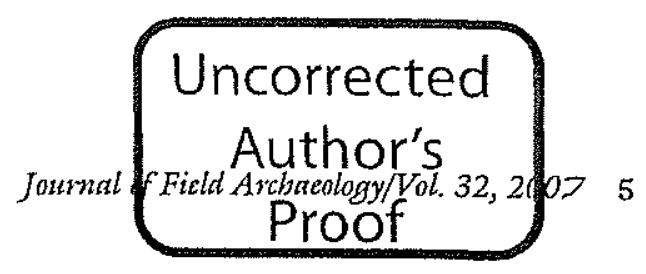

Table 1. Radiocarbon dates (ranked by median calibrated date A.D.) from sites discussed in the text. All dates except C427 are AMS dates. Calibrations were calculated using CALIB version 5.0 (Stuiver and Reimer 1993).

\begin{tabular}{|c|c|c|c|c|c|c|}
\hline Site & Proveniena & $14 C$ age n.P. & $\begin{array}{l}\text { Calibmited year manges } \\
\text { A.D. (2 sigynas) }\end{array}$ & $\begin{array}{l}\text { Calibmated datc A.D. } \\
\text { (median) }\end{array}$ & Sample no. & Latb no. \\
\hline Queirnada & Rm. 3 hearth & $385 \pm 55$ & $559-721,741-770$ & 647 & $\mathrm{C} 206$ & GX-21332 \\
\hline Costa \#2 & Rm 3 hearth & $1295 \pm 60$ & $647-877$ & 731 & $\mathrm{C} 276$ & $G X-21330$ \\
\hline Costa \#2 & Exterior rm 3 & $1256 \pm 61$ & $655-894$ & 763 & $\mathrm{C} 275$ & AA 62725 \\
\hline Raposeira & Subfloor & $1215 \pm 50$ & $675-898$ & 807 & C264 & $\mathrm{GX}-21335$ \\
\hline Costa \#2 & Rn 3 hearth & $1208 \pm 63$ & $674-903,914-969$ & 816 & $\mathrm{C} 278$ & AA62726 \\
\hline Pego Real 1 & & $1190 \pm 60$ & $688-754,757-973$ & 834 & $\mathrm{C} 30 \mathrm{I}$ & $\mathrm{GX}-21338$ \\
\hline Queimada & $\operatorname{Rm} 2$ & $1175 \pm 50$ & $708-747,766-983$ & 851 & $\mathrm{C} 203$ & GX-21333 \\
\hline Queimada & $\mathrm{Rm} 2 \mathrm{sw}$ & $1160 \pm 40$ & $775-979$ & 873 & C208 & AA62720 \\
\hline Queimada. & $\operatorname{Rin} 2$ & $1142 \pm 39$ & $801-985$ & 903 & $\mathrm{C} 201$ & AA62719 \\
\hline Raposeira & Rm l hearth & $1055 \pm 39$ & $894-1028$ & 985 & $\mathrm{C} 25 \mathrm{l}$ & AA62722 \\
\hline Costa $\# 2$ & $\mathrm{Rm} 2$ & $1045 \pm 50$ & $886-1049,1084-1124$ & 990 & $\mathrm{C} 277$ & $G X-21331$ \\
\hline Alcaria Longa & House 1 hearth 23 & $1012 \pm 37$ & $967-1053,1079-1153$ & 1018 & $\mathrm{C} 423$ & AA62733 \\
\hline Alcaria Longa & House $8 \mathrm{~b}$ hearth & $1008 \pm 62$ & $894-1164$ & 1031 & $\mathrm{CA04}$ & AA62727 \\
\hline Alcaria Longa & House 1 silo & $993 \pm 62$ & $941-1185$ & 1054 & $\mathrm{CA} 22$ & AA62732 \\
\hline Alcaria Longa & House 5 & $970 \pm 50$ & $984-1185$ & 1087 & C429 & GX-21337 \\
\hline Alcaria Longa & House $8 \mathrm{~b}$ & $965 \pm 50$ & $987-1185$ & 1090 & $\mathrm{C} 428$ & GX-31336 \\
\hline Alcaria Longa & House 1 hearth 2 & $938 \pm 60$ & $995-1217$ & 1103 & C410 & AA 62728 \\
\hline Alcaria Longa & House 4 hearth 9 & $929 \pm 60$ & $1012-1221$ & 1108 & $\mathrm{C} 418$ & $\mathrm{AA} 62731$ \\
\hline Profile \#5 & Stone line & $890 \pm 40$ & $1035-1219$ & 1137 & $\mathrm{C} 430$ & GX-30696 \\
\hline Alaria Longa & House 2 hearth 7 & $872 \pm 61$ & $1034-1260$ & 1158 & $\mathrm{C} 417$ & AA62730 \\
\hline Alcaria Ionga & House 4 & $855 \pm 89$ & $1017-1287$ & 1165 & $\mathrm{C} 416$ & AA62729 \\
\hline Queimada & $\mathrm{Rml} \mathrm{NE}$ & $530 \pm 39$ & $1312-1358,1387-1444$ & 1407 & C210 & AA62721 \\
\hline Altcaria Longa & Top structure & $460 \pm 75$ & $\begin{array}{l}1313-1358,1387-1533 \\
1536-1635\end{array}$ & 1455 & $\mathrm{C} 427$ & GX-16307 \\
\hline Raposcira & Locus 5 & $440 \pm 62$ & $1398-1533,1536-1635$ & 1469 & $\mathrm{C} 263$ & AA62724 \\
\hline Raposeira & Locus 5 & $285 \div 50$ & $1460-1673$ & 1580 & $\mathrm{C} 261$ & GX-21334 \\
\hline Raposeira & Locus 2 & $198 \pm 46$ & $\begin{array}{l}1641-1707,1719-1827 \\
1832-1887\end{array}$ & 1771 & $\mathrm{C} 256$ & AA62723 \\
\hline
\end{tabular}

the thumb-impressed motif starts to decline and the later "Islamic" style tiles begin to appear. Our best estimate is that the change occurs between A.D. 850 and 950 . In 1995, we tested this typological distinction by excavating house compounds from three of the sites identified as Transitional in age on the basis of rooftile type: Queimada, Costa \#2, and Raposeira (FIG. 2; Boone 2002). Queimada, which dates somewhat earlier (TABLE I) contained only thumbimpressed tiles; Costa \#2 and Raposeira contained both types, although thumb-impressed tiles predominated. Radiocarbon dates (TABLE $\mathrm{r}$ ) verified that none of these sites was occupied past A.D. 950 to 1000 (not including three intrusive deposits dating to the 15 th and 16 th centuries, explained below)

Transitional utilitarian pottery consists of hand-formed cooking and water storage wares produced from local clays, with increasing frequencies of wheel-made pottery (plainwares) in the later part of the period (TABLE 2). Based on these excavations, Transitional and early. Medieval Islamic sites (late 6th through the 10th centuries A.D.) are hamlets consisting of one or two tile-roofed houses built of dry-stone masonty (Boone 2002).

Transitional period hamlets also have a distinctive spa- tial distribution in the survey area. They are clustered in the vicinity of the largest Late Roman villa site, Cerro da Loiça, and soil maps indicate that they tend to be preferentially located in an area of relatively good agricultural soils called pardos mediterránicos (Carta dos Solos de Portugal 1961). In contrast, the rest of the survey area consists almost entirely of thin lithosols and frequent rock outcrops. A onesample chi-square test indicated a statistically significant preference for these soils (chi-square $=14.01$, critical value $=3.84$ at a 0.05 level of significance), in contrast to earlier Roman and later Medieval Islamic sites which are much more evenly distributed across soil types. Although it is clear that the soil distributions we observe today have been altered by erosion and redeposition since the Medieval period, we assume that patches of deep, higher quality soils represent the remnants of higher quality soils that existed there in the past.

One of the main implications of these data is that small hamlets and villages began to appear in the region perhaps 50 to 100 years before the Muslim invasion of A.D. 711 , and they continued with no radical break in material culture, other than a gradual increase in the frequency of wheel-made common wares, until about A.D. 950-1000. 
Table 2. Proportions of hand- and wheel-made pottery from excavations of Transitional period sites (Queimada, Raposeira, and Costa \# 2) and one later Islamic period sitc (Alcaria Longa).

\begin{tabular}{|c|c|c|c|c|c|c|c|}
\hline Sitc & $\begin{array}{l}\text { \% Coarse red-bromen } \\
\text { (hand-made) }\end{array}$ & $\begin{array}{l}\text { \% Coarse red-brown } \\
\text { (whel-made) }\end{array}$ & $\begin{array}{l}\text { \%o Orange plainurares } \\
\text { (wheel-made) }\end{array}$ & $\begin{array}{l}\text { of Beige plainwreses } \\
\text { (whecl-made) }\end{array}$ & $\begin{array}{l}n \\
\text { melodo }\end{array}$ & $\begin{array}{l}n \\
\text { terma sigilats }\end{array}$ & sh \\
\hline Queimada & 31.4 & 17.0 & 47.5 & 3.6 & 0 & 1 & 223 \\
\hline Raposcira (Early) & 12.3 & 77.1 & 10.1 & 0.002 & 0 & 2 & 741 \\
\hline Raposeira (Late) & 0.0 & 21.3 & 77.6 & 0.9 & 1 & 0 & 103 \\
\hline Costa \#2 & 0.0 & 18.0 & 80.1 & 1.8 & 0 & 0 & 111 \\
\hline Alcaria Longa & 0.0 & 17.2 & 75.2 & 4.4 & 166 & 0 & 5196 \\
\hline
\end{tabular}

\section{Late Medieval Islamic Settlement}

157 Medieval Islamic period sites consisting chiefly of scatters of building stone, rooftiles, and pottery ranging from 100 sq $\mathrm{m}$ to 4 ha, were recorded (FIG. 3). By distinguishing between Transitional period and later Medieval Islamic period village sites on the basis of imbrex tile designs, we are able to make some tentative statements about changes in site character and distribution. At around A.D. 950 to 1000 , small Transitional hamlets were abandoned and larger aggregated villages, exemplified by Alcaria Longa, were constructed in hilltop locations. Numerous smaller sites, probably consisting of single household dwellings, small hamlets of a dozen or fewer house compounds, as well as agricultural field houses also appear on the landscape at this time. Based on the difference between Transitional and later Medieval Islamic period site numbers, it is tempting to infer a period of nearly explosive growth in settlement density at around A.D. 950-1000. Since none of the small sites identified as later Medieval Islamic on the basis of rooftile designs and surface pottery has been excavated, however, we cannot be sure whether the occupation of these small sites extends back into the A.D. 800s or whether many continue to be occupied through the 11th and 12th centuries, as do the larger aggregated hilltop sites. In all likelihood, many of the smaller "later Medieval Islamic" sites represent a continuation of the growth of Transitional period settlements discussed above, and this growth culminated in the formation of aggregated hilltop sites in the mid- to late-10th century. Furthermore, it is unlikely that all the sites were occupied at the same time. It seems more likely that there was a certain amount of settlement movement around the landscape and even cyclical abandonment and reoccupation of specific sites.

During the later Medieval Islamic period, hand-formed pottery disappeared and was replaced by distinctive Islamic ceramics, including both cooking vessels and wares used for the serving of food and drink. Imported glazed wares, predominantly manganese-painted, honey-colored (melado) wares characteristic of the Caliphal and Taifal periods (10th through the early 12 th centuries A.D.) are present in small quantities (TABLE 2). The largest of these villages con- sisted of between 10 and 40 house compounds. Radiocarbon evidence from Alcaria Longa (TABLE I) indicates that these settlements were occupied for the next 150 to 200 years and then abandoned some time around A.D. 1150, nearly 100 years before the conquest of the area by the Portuguese Christians in A.D. 1238.

Excavations carried out between 1988 and 1994 at the late Medieval Islamic period village site of Alcaria Longa (Boone 1993, 1994, 1995, 2002) revealed a village consisting of about 35 multi-structure house compounds covering an area of $1.6 \mathrm{ha}$. The primary occupation began ca. A.D. 950 to 1000 and the site was abandoned around A.D. 1150. A locally produced rooftile recovered from one of the house compounds was incised with a brief inscription in Arabic (Boone 1995: fig. 8), implying that the villagers were Arabic speakers and writers, although not necessarily that they were Muslims. A silver Arabic coin minted in the name of Ibn Qasi, the Sufi rebel leader of Mćrtola from A.D. 1144 to II46 (Antunes and Sidarus 1993) was found directly on the floor of one of the house compounds, along with two silver rings with glass stones. The coin and its context may date the approximate and abrupt abandonment of the site, which is corroborated by the radiocarbon evidence. The coin had been perforated with two holes for wear as jewelry, and another perforated coin, a silver filigree earing, pieces of a silver chain, and stone beads were recovered in excavation (Boone 1993, 1995).

Faunal remains preserve very poorly in the region due to acidic soil conditions, but a preliminary analysis of 225 bone elements recovered at Alcaria Longa indicated the presence of sheep/goats $(69.7 \%$ of the number of identified specimens), cattle $(13.2 \%)$, deer $(2.6 \%)$, rabbits/hares $(2.6 \%)$, and $\operatorname{dog}(2.6 \%)$, as well as two elements of quail or partridge; there were no wild or domestic pig remains (Antunes 1996). Whole and fragmentary circular handpowered millstones for grinding cereals are numerous at the site, and are frequently found on the surface of other Medieval Islamic period sites.

The abandoned 11 th and 12 th century villages of this region, which, as we have discussed above are quite numerous and visible on the ground surface, are known locally as alcarias. The term refers specifically to the niins of 

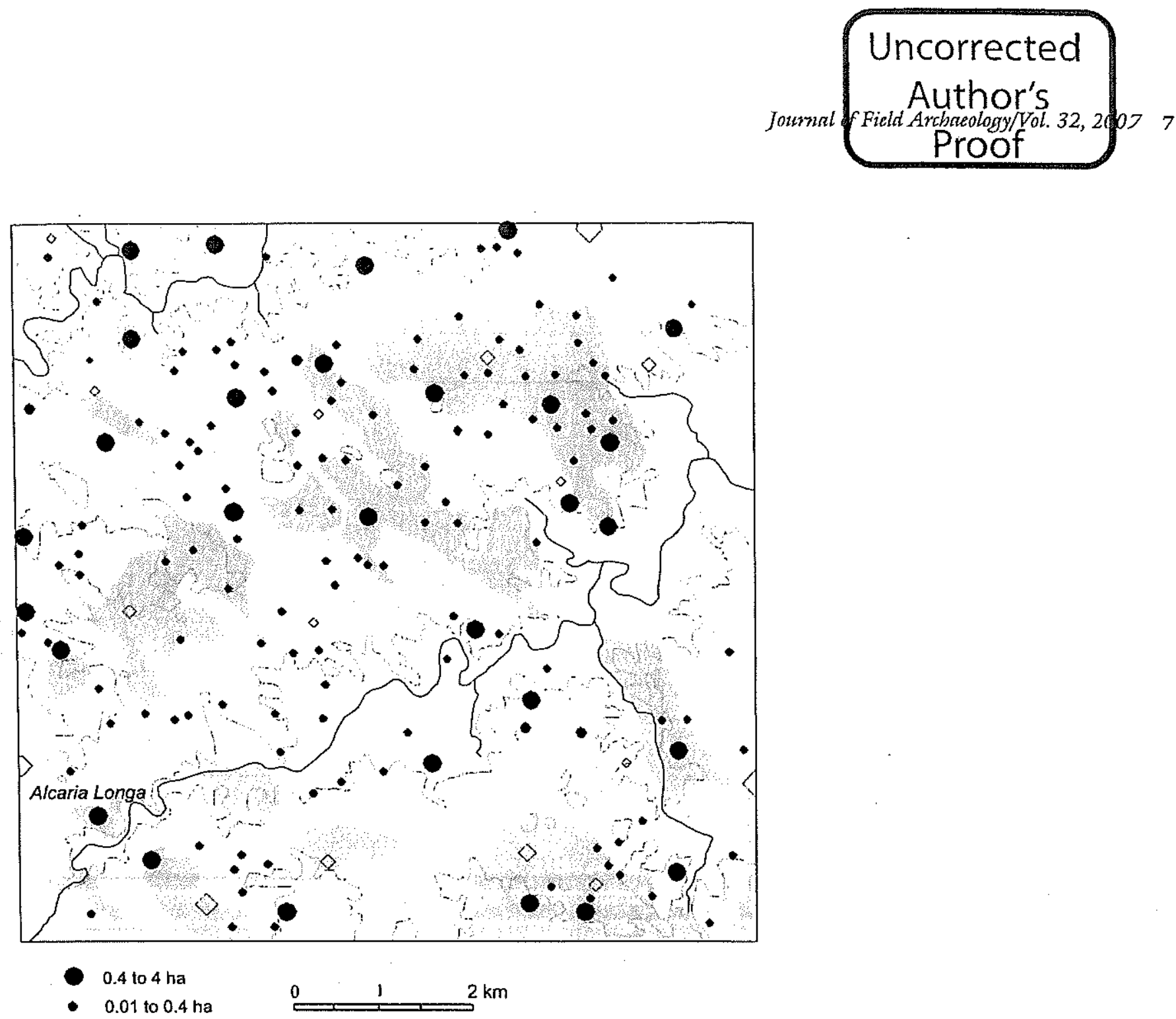

Figure 3. Map of the $8 \times 8 \mathrm{~km}$ survey area showing the location of Medieval Islamic period and modern settlements (black dots and open circles respectively). Site (in italics) is discussed in the text. Gray areas denote higher quality soils.

deserted villages which local inhabitants are aware were Medieval Islamic period settlements (i.e., "sitios dos Mouros"). Some of the more extensive ruins are noted as alcarias on the mid-20th century Cartas Militares, topographic maps produced by the military, which record a wealth of local toponymic lore reflecting a cultural landscape that has now all but disappeared. Some modern villages in the area are named after nearby ruins as is, for example, the modern village of Alcaria Longa, located about $1.5 \mathrm{~km}$ from the site discussed above. Alcarias located near modern settlements have often been mined for building stone, and Medieval period architectural elements like door lintels, thresholds, and millstones can often be seen incorporated into the dry-stone masonry walls of modern structures.

The term alcaria clearly derives from the Arabic word alqarya (pl. al-qurá), denoting a village. In southern and eastern Spain, al-qurá are typically associated with small castles or towers (busun, sing. hisn). There, the hisn-qarya complex, which appears to be strongly associated with irrigation agriculture rather than dry farming, is seen by some as the archaeological signature of Arab and Berber tribal settlement of the Andalusian landscape (Bazzana, Cressier, and Guichard 1988; Glick 1995), and as paralleling the pattern of incastellamento, or appearance of castles and towers over the European countryside during the late 10th and 11th centuries A.D. in western and southern Europe (Hodges 2003; Toubert 1990), where it was coincident with the solidification of the feudal system. We note here that the dense distributions of village sites found in the survey lack associated fortifications, and there is little evidence of a hisn-qarya pattern, as it is understood in eastern and southern Spain, in the Lower Alentejo of Portugal (although cf. Argemi Relat, Bruy, and Soler Chic 1993 in 


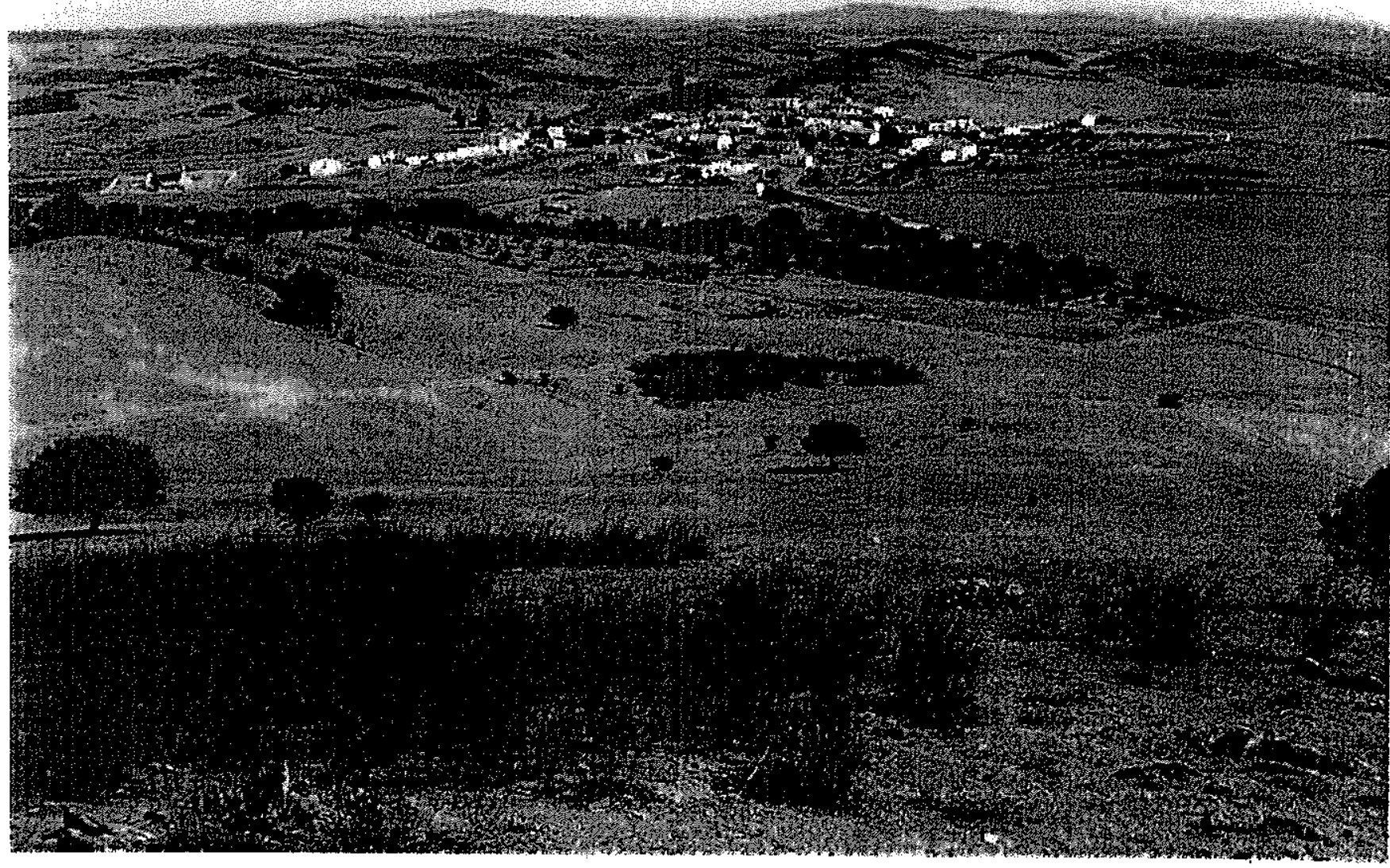

Figure 4. Photograph of the survey area taken in 2005, illustrating typical landforms and vegetation.

View is to the north, from a hill overlooking the montc, or village, of Goias.

connection with Alcaria Ruiva, a village located to the north of the survey area).

\section{Christian Medieval Period and Modern Period Settlement}

After the conquest of Mértola by the Portuguese in A.D. 1238 , the entire region came under the control of the military Order of Santiago, which established its headquarters in the alcafoura (citadel) of Mértola. 14 Christian Medieval to Modern period settlements in the survey area are still occupied today, consisting of three sedes da freguesia (large villages of up to about 250 people that serve as parish seats, with associated churches dating to the 15th century), seven montes (small aggregations of households with populations ranging from 5 to about 100), and four quintas (household compounds, storage and work buildings of large landowners, more or less equivalent to haciendas). The survey data indicate that most Christian Medieval to Modern period rooftile and stone scatters are related to agricultural outbuildings. Only two post-Islamic Medieval period sites represented residential sites that were later abandoned, and these were quite small.

The Christian Medieval to Modern period settlements tend to be located down in valleys and hollows, and are rarely, if ever, located on top of earlier Medieval Islamic period settlements, which tend to be positioned on hilltops and hillsides. Like the Transitional period sites, these later settlements are strongly associated with the deeper pardos mediterránicos, or grey Mediterranean soils. Perhaps the parallel here is that both the Transitional and Modern set- 


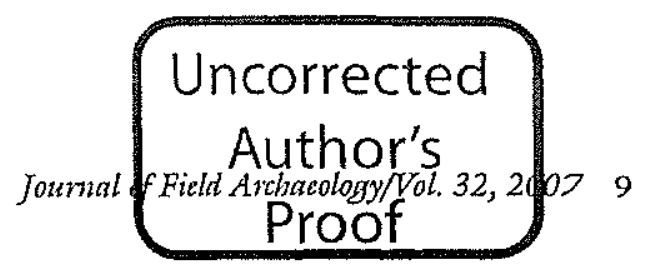

tlements mark new foundations in an area that had lain fallow for some time; hence they chose what remained of the best soils for settlement.

The first church inventory of the concelho (cointy), of Mértola appears in 1482, and records parochial churches that correspond to those existing today in our survey area (Barros, Boiça, and Gabriel 1996). It also records the names of a few small montes in the vicinity of the churches that are still occupie". A royal census taken in 1527 (Colloço 1931) ind: ites that the entire concelho, encompassing apprately $11,000 \mathrm{sq} \mathrm{km}$, contained only five named scttlements (including Mértola) and 550 isolated farmsteads (casas apartadas). Some of these isolated houses probably formed the nuclei of the montes and parish seats that exist today. By 1752 , another census of the concelho of Mértola shows that all of the montes and parish seats in the survey area that exist today were already in place, along with their present day place-names (Santos 1987). According to census figures from the late 19th century on, the concelho reached its peak population in 1920 at about 23,000 , a figure that held steady until 1950 . This period coincides with a program initiated by the Salazar regime to intensify cereal production in the Lower Alentejo, and which led to a significant, and, today, highly visible, amount of soil degradation, erosion, and soil loss: Between 1950 and 1990 , the county lost $60 \%$ of its population to emigration, and was down to about 9000 people in 1990. Following the inception of the European Economic Community, the region has experienced a modest demographic rebound.

\section{Radiocarbon Dating}

A total of 26 radiocarbon dates were obtained in excavation in the study area (TABLE I). Fourteen dates were taken from excavations of the Transitional period sites of Raposiera (5), Queimada (5) and Costa \#2 (4), and one sample from the Transitional period tile kiln site of Pego Real was dated. Ten dates are from excavated contexts at the later Medieval Islamic period village of Alcaria Longa. An additional date was obtained from a charcoal fragment, collected from a stratum that included both a stone line and Islamic period artifacts in floodplain deposits at Profile No. 5 (below).

The dates support arguments made above that a clear chronological distinction existed between sites defined as Transitional and the later Medieval Islamic period site of Alcaria Longa. Transitional sites were occupied from the end of the Late Roman period to the early Medieval Islamic period. There does not appear to be any sharp break in settlement density or type after the Muslim invasions of A.D. 711, although there is evidence of a vigorous increase in human activity in the 9 th and.10th centuries A.D. In fact, from the perspective of rural settlement, the Transitional period appears to be all of one piece, spanning most of Late Antiquity from the 7 th through the 10th centuries. The dates also indicate that Alcaria,Longa was not occupied past the mid-12th century A.D.'

The five latest dates, beginning in the late 14 th century A.D., require further comment. The first late date, from Queimada (C210), was from a sample recovered just above the roof fall layers of one of the interior rooms. Stratigraphically, it was expected to post-date the occupation of the site. The late date from Alcaria Longa (C427) was recovered from the floor of a hilitop structure, probably a military observation post, that was distinct from the rest of the occupation area of the site, and which was known to be Christian Medieval in age on the basis of associated ceramics. The three late dates from Raposeira (C256, C261, and $\mathrm{C263}$ ) were recovered from what we now recognize as a disturbed or intrusive deposit of charred material associated with one or more brush fires in the Christian Medieval period or early Modern period. They may even be associated with burn-offs related to the 15 th- and 16th-century resettlement of the area discussed above. Archaeobotanical analysis of all the charcoal samples is currently underway.

The dates provide a record of the intensity of human occupation in the area from the Late Roman through the Medieval and Modern periods. Figure 7 presents a histogram of the median probability dates (dates at which there is equal area under the probability curve to the left and right) of all 26 radiocarbon dates. Since Roman villas in the study area were in all cases abandoned in the 5 th or 6 th centuries A.D. at the latest and were not reoccupied, no dates from the Roman period appear. The dates reflect the first appearance of hamlet settlements in the 7 th century and increasing settlement density in the 9 th and 10th centuries. The lack of a representative, or in fact, any kind of sample from small sites identified as "later Medieval Islamic" almost certainly means that there is underrepresentation of the growth in settlement density in the 9th and 10th centuries. The four Christian Medieval and early Modern dates indicate a later reoccupation of the landscape.

\section{Geoarchaeological Investigations}

The settlement and radiocarbon evidence suggests a period of rapid settlement growth during the Late Roman and the early Medicval Islamic periods ( 7 th through the 10th centuries A.D.). The data show that the majority of, if not all, rural sites were abandoned 50 to 100 years before the Reconquista; clcarly the arrival of the Christians did not cause depopulation of the countryside. Because of the dramatic increase in rural population densities that we have 


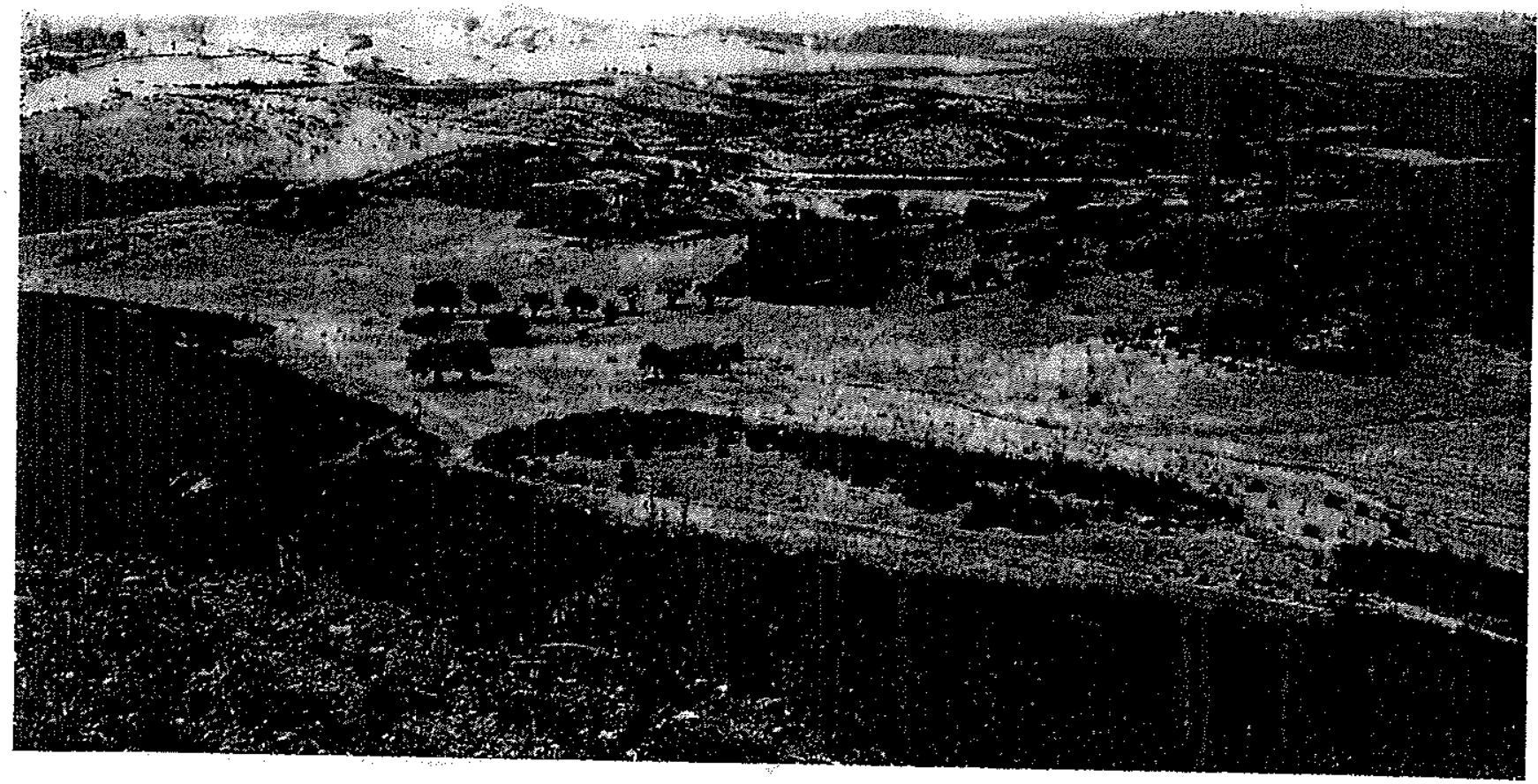

Figure 5. Photograph of the later Medieval Islamic period site of Alcaria Longa taken in 1992 from the top of a hill to the east of the site. Large Medieval Islanic period sites were favored planting locations for olive trees during the early Modern period. Many of the trees visible here are several hundred years old with trunks up to a meter in diameter. The parochial church of São Miguel do Pinheiro, daring to the 15 th century, can be seen on the horizon in the upper left.

documented for the Medieval Islamic period, we hypothesized that anthropogenic environmental degradation might have been a factor leading to the subsequent abandonment of rural sites. To investigate this possibility, we initiated geoarchacological studies of long term humanlandscape interactions in the study area.

\section{Land-use and Environmental Change}

An extensive literature has been generated by researchers investigating past landscape change in the Mediterranean region (e.g., Ballais 2000; Bintliff 1992; Chester and James 1991, 1999; Pope and van Andel 1984; Potter 1976; Stevenson and Harrison 1992; van Andel and Runnels 1986; van Andel, Zangger, and Demitrack 1990; Van Der Leeuw 2000; Vita-Finzi 1976; Wainright 1994). These studies focus on soil development, erosion, and al- luviation, especially as related to significant changes in land-use. Generally, regional studies have attempted to determine the timing of cycles of erosion and deposition over large areas and in multiple drainage basins in order to discern whether landscape change was caused by humans or by climatic variation, and there is continued debate concerning the relative importance of human impacts and external climate changes (i.e., changes in precipitation, temperature and plant cover) in causing landscape change.

There has been a similar debate in the American Southwest for the past half-century concerning anthropogenic vs. climatic causes for erosion and particularly for incision and aggradation in ephemeral stream systems (e.g., Bahre 1991; Bryan 1940, 1942; Bull 1991, 1997; Cooke and Reeves 1976; Hall 1980; Hereford 1984; Lcopold 1976; Schumm and Parker 1973). Recently, there has been a 


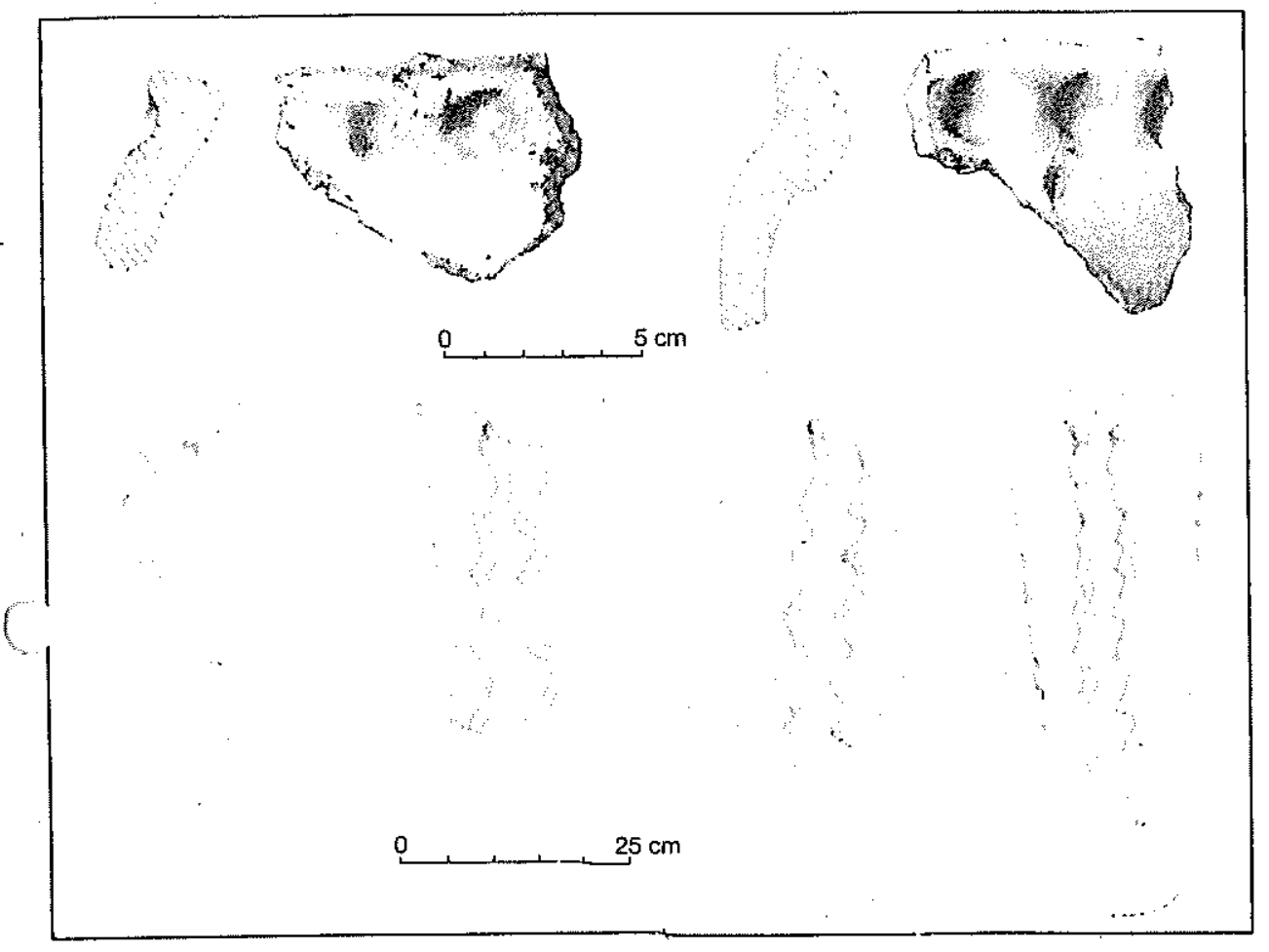

Figure 6. Drawing showing the difference between early Transitional period thumb-impressed rooftiles (top), and later Medieval Islamic period rooftiles.

growing emphasis on investigating the processes related to geomorphic change (e.g., Bull 1997; Ritter, Kochel, and Miller 1995) and some researchers have argued convincingly that it is necessary to focus on localized areas and small drainage basins in order to minimize the number of variables affecting landscape change and the effects of the complex behavior of fluvial systems (e.g., McFadden and McAuliffe 1997; Tillery et al. 2003). Compared to most of the investigations that have been undertaken in the Mediterranean region, these studies are closer in scale and purpose to the kind of localized study we present here. In our investigations, the guiding principle was that this type of study is best carried out in a relatively small area with uniform bedrock, topography, climate and biota, and focused on the processes of geomorphic change (see Thornes 1987; Thornes and Gilman 1983 for examples of broadly similar work in Iberia). We suggest that this approach can provide more detailed insights into human-landscape interactions than the regional studies that document landscape change without thoroughly exploring, the articulation between effect and supposed cause.

\section{Previous Geological Research}

Chester and James $(1991,1999)$ have published exten- sive analyses of alluviation in the Algarve region of Portugat, the southern coastal littoral immediately to the south of out study area. They found two significant erosional phases oceurring between 2000 and $\$ 00$ B.P., cothciding with the mid-Roman and Medieval periods. They tested three possible hypotheses regarding the causes of crosional events: climatic, antirropogenic, and crossing of intrinsic thresholds in fluvial systems. To detect changes through time in vegetation, Chester and James used pollen recovered from lake cores from alpine lakes in the Serra da Estrela, some $350 \mathrm{~km}$ to the north. Their analyses of local geomorphology and fluvial stratigraphic sequences, however, provided direct evidence of local landscape change and of the intensity of land-use during the Roman and Medieval periods. Their investigation of sedimentation and incision of stream systems adjacent to Roman and Islamic period sites suggests anthropogenic causes for erosional episodes. As evidence, they showed that charcoal contained in strata indicative of rapid hillslope erosion and floodplain deposition could be dated to the Roman and Medieval Islamic periods. They argued convincingly that the charcoal originated in nearby sites dating to those periods and was redeposited in stream beds by widespread erosion. Their studies emphasize the need to coordinate geomorphic evidence 


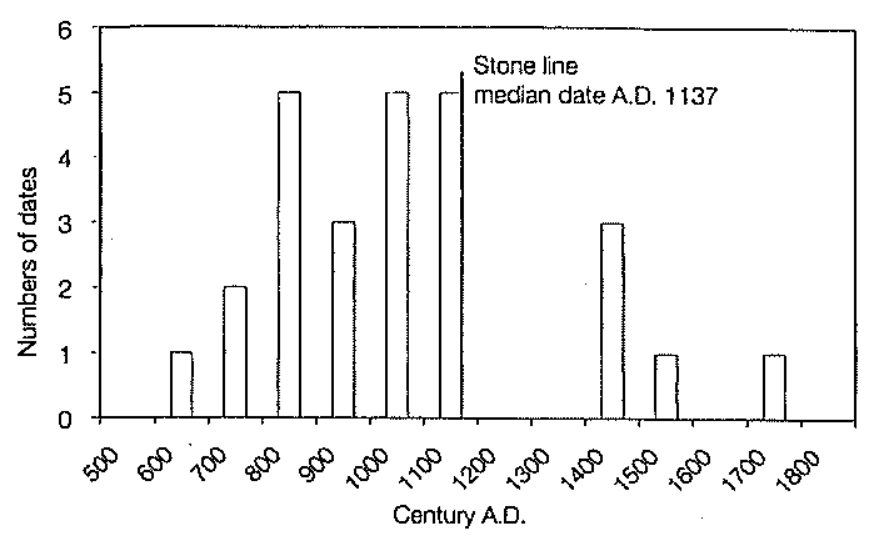

Figure 7. Histogram of 26 calibrated median radiocarbon dates from Table 2, showing the gap in dates between about A.D. 1150 and 1450 .

with archaeological data; our research was designed to do just that.

\section{Stratigraphic Studies}

In 2003 and 2004, we conducted geoarchaeological investigations in our study area, focusing attention on sediments and soils in two geomorphic contexts. First, we took advantage of the recent downcutting of ephemeral streams and examined the floodplain deposits emplaced in the past by those stream systems. We also investigated the soils on and at the bases of hillslopes near sites recorded during the 1992 survey. The current incised channels formed during the 20th century because of widespread changes in landuse, specifically the intensification of cereal production during the Salazar regime and especially the use of tractors in cultivating large areas since the 1980s. Mechanically removing plants and plowing soils on hillslopes increases runoff as well as sediment yield. After an initial period of alluviation, the increase in runoff, discharge, and stream competence (the power to move clasts and sediments) favors channel formation. These processes may provide a good analogy for past anthropogenic landscape change.

Soils form slowly on stable geomorphic surfaces and soil horizons, either at the surface or buried, and represent extended periods of landscape stability. In addition, soil development follows a more-or-less predictable trajectory such that the degree of development can be used to determine roughly how long a soil has been forming (e.g., Birkeland 1999; Harden and Taylor 1983; Huckleberry 2001). The rates and trajectories of soil formation vary with parent material, climate, organic inputs, and other conditions, and it is necessary to control for these variables. Degrees of soil development cannot be assumed to reflect the same chronological information in widely separated areas. Combining pedological (soil-related) and stratigraph- ic data from both fluvial and upland contexts, our research consistently produced evidence of at least two major periods of erosion during the past 2500 years.

\section{Methods}

We chose seven loci of exposed floodplain strata in our study area for detailed examination. We selected these fluvial profiles for their potential to produce several kinds of relevant data. We sought locations where relatively deep modern channels revealed visibly stratified deposits that we suspected were likely to reflect distinct alternating periods of erosion, deposition, and soil development. In addition, we chose locations near Roman and Medieval village sites in order to maximize the likelihood of encountering temporally diagnostic artifacts and other materials eroded from settlement areas. The artifacts and, in one case, charcoal fragments suitable for radiocarbon dating, provided one means of estimating the ages of different strata.

Another consideration in selecting loci for study was our desire to focus on small drainage basins, with catchments of less than $0.5 \mathrm{sq} \mathrm{km}$. By doing so, we hoped to minimize some of the complexities of interpreting fluvial stratigraphy. The problem of complex response (e.g., Patton and Schumm 1981; Schumm and Parker 1973), in which one change in external variables (precipitation) can produce multiple adjustments (i.e. multiple episodes of incision or aggradation) in the fluvial system, is less pronounced at higher elevations in that system. In other words, the effects are minimized at locations with smaller drainage basin size, where the stream interacts directly with more hillslope deposits and fewer redeposited floodplain materials. In addition, we selected sites such that important factors including bedrock geology, topography, climate, biota, and modern land-use practices were comparable within and between study units.

To investigate hillslope deposits, we excavated two series of soil test pits, one on the slope adjacent to the Transitional period site of Queimada, and a second on the slope adjacent to the later Medieval Islamic period village of Alcaria Longa. In each case, we placed our test pits to sample the different geomorphic sections of the slopes: the summit, shoulder, backslope, footslope, and toeslope (Birkeland 1999: 231), alternately, the summit, convex, straight, concave, and base segments (Ritter, Kochel and Miller 1995: 127). Differences in the soils and deposits at these locations reflect catenary (slope-related) processes; among other things, erosion results in the removal of deposits from higher parts of the slope and redeposition at lower positions. These investigations are important for two reasons. They can yield relatively straightforward evidence of past landscape change, and the information concerning the 


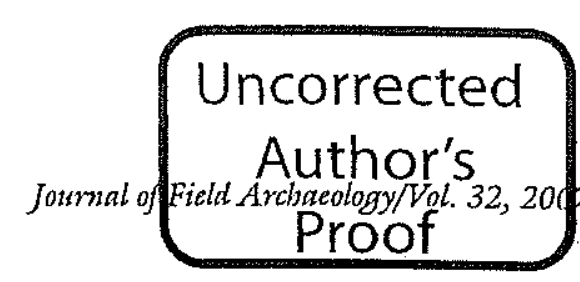

\section{Profile $1 \quad$ Profile $3 \quad$ Profile 4}

Profile 5

Profile 7
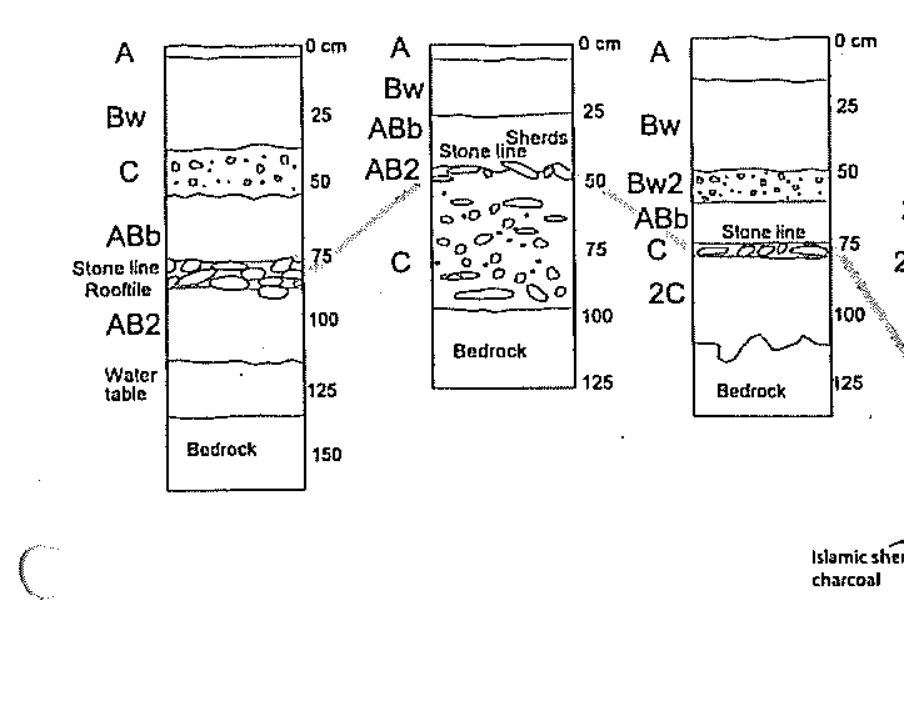

Figure 8. Diagram of five soil profiles discussed in the text, showing the stone line indicative of a cycle of erosion dating to the mid-12th century A.D.

timing of movement of sediments on the slopes provides a firm basis for interpreting fluvial stratigraphy, specifically differentiating evidence for landscape change from strata emplaced or altered by complex responses.

For each of the seven fluvial profiles and 10 soil test pits, we excavated cuts to bedrock and recorded detailed soilstratigraphic (or pedostratigraphic) profiles. Characteristics of each soil horizon and stratum were recorded using standard field methods (Birkeland 1999: 347-359; Buol et al. 1997; Soil Survey Staff 1975, 1993). For fluvial contexts, we paid particular attention to clast characteristics such as size, sorting, orientation, and rounding because these reflect source areas, degree of transport, amount of time exposed to flowing water, and stream competence. The boundaries between horizons were described and the presence of krotovina (rodent or insect burrows) and any unusual characteristics were noted.

\section{Floodplain Stratigraphy}

Figure 8 presents profiles of five of the fluvial sections we recorded. It shows soil horizon designations, clastic content, and the stratigraphic locations of artifacts and a stone line that was present in each study unit. The stone lines represent the bedloads of incised streams, providing evidence for a past episode of channel formation and erosion of floodplain deposits. Degrees of soil formation, the presence of buried soil horizons, and the presence of artifacts facilitates correlation between study units. Profiles 2 and 6 are not presented here because the stratigraphy at those loci was atypical of the fluvial contexts we investigated. Rather, they were recorded to provide baseline information on hillslope soils and as part of an unsuccessfial attempt to recover preserved pollen.

Profile 1 is located in the small wash below the Transitional period site of Queimada and Profiles 3 and 4 are in a small wash near the Roman site of Cerro da Loiça. Each exposes a series of strata deposited and/or reworked by small seasonal streams. The basal sediments appear to reflect an initial period of rapid colluvial deposition antedating significant occupation of the area by people practicing agriculture; they probably are associated with landscape adjustment to climate changes at the Pleistocene-Holocene transition. The superjacent strata are stone lines, the bedloads of incised streams similar to those present today. Artifacts recovered from these strata in Profiles 1 and 3 show that arroyo formation, and probably significant hillslope erosion, occurred during or after occupation of the nearby sites. The expressions of time-dependent pedogenic characteristics in the directly overlying strata reflect a protracted period of landscape stability and soil formation. The remaining strata exhibit little to no evidence of soil formation, suggesting recent, rapid deposition.

Profiles 5 and 7 are located where small tributary streams cut through floodplain deposits and join the much larger Ribeira do Carreiras. Profile 5 is located downstream (along the tributary) from a small, unnamed Medieval Islamic period site and Profile 7 is below the Medieval Islamic period village of Alcaria Longa. The stratigraphy in 
the two locations is very similar, with the exception that the lack of artifacts in the deepest deposit at Profile 7 suggests that it was emplaced before occupation of the site. Clast characteristics show that the superjacent unit at Profile 7 and the basal stratum at Profile 5 were deposited by the tributary streams and then buried after a relatively short period of time; both appear to reflect erosion in the drainage basins of the tributary streams. In both cases, the overlying stratum is a stone line in which the clasts are rounded, imbricated, and of a relatively uniform size. They reflect an extended period of landscape stability with tributaries debouching onto the floodplain of the ribeira at constant elevations. The higher units were emplaced by deposition on the floodplain due to overbank flooding of the ribeita, with the exception of a single horizontally discontinuous lenticular unit deposited by the tributary stream at Profile 5. None of these strata exhibit significant pedogenesis; they were deposited and then buried before soils formed. It is likely that these sediments entered the fluvial system because of widespread erosion of hillslope soils related to changes in agricultural practices during the 20th century.

Several artifacts were recovered from the deepest stratum at Profile 5, including a fragment of a melado-glazed redoma, a narrow-mouthed, long necked bottle or cruet diagnostic of the Califal and Taifal periods of the late 10th through the 11th centuries A.D. Similarly, numerous artifacts derived from the site of Alcaría Longa were present in the stratum above the basal unit at Profile 7. A charcoal fragment from the basal stratum in Profile 5 was AMS dated to between A.D. 1035 and 1219 (two sigmas), with a median calibrated date of A.D. 1137 (TABLE I: SAMPLE $\mathrm{C} 430$ ). Because charcoal is fragile and highly mobile in fluvial systems, it is likely that this date closely approximates the timing of erosion in the drainage basin. Alternatively, it is possible that erosion some time after the Medieval Islamic period exhumed cultural sediments from the sites above each profile and transported them into the streams. The sites are still readily visible at the surface, however, and there were no artifacts or charcoal visible in the superjacent strata that originated in the drainage basins where the sites are located. The ubiquity of artifacts and charcoal in the basal stratum at Profile 5 and in the stratum above the basal deposit in Profile 7 therefore suggests that cultural materials entered the fluvial systems while the sites were still occupied or shortly thereafter. The data suggest that major hillslope erosion removed sediments and artifacts from hillslopes into the fluvial system during the late Medieval Islamic period.

\section{Hillslope Soils Below Alcaria Longa and Queimada}

The soils exposed in test pits at the summit and backs- lope locations on both hills reflect extreme erosion in the past as well as recent and ongoing removal of sediments. The plowed soils are thin and rocky and they exhibit weak expression of time-dependent pedogenic characteristics. They rest directly on and in the interstices in bedrock, implying that surface sediments were completely stripped from these locations in the past. Artifacts in contact with bedrock in the test pit at the backslope location adjacent to Alcaria Longa show that the sediments there were removed during or after the Medieval Islamic period, and similar degrees of soil development imply that soil loss was at least roughly contemporaneous on the slope next to Queimada.

The soils we examined in the test pits at the shoulders of both hills were only slightly different from those at the summit and backslope locations. On the slope adjacent to Queimada, the sediments include a weakly-developed rocky soil at the surface that is practically identical to the surficial deposits higher and lower on the slope. Unlike what we observed at other locations, the surface horizon is underlain by a well developed, clay enriched soil horizon contained within interstices in the bedrock; structure, texture, and clay film morphology demonstrate a significantly greater age for the lower soil horizon. This suggests that the episode of severe erosion in the past left some discontinuous areas of remnant hillslope deposits intact. The test pit on the shoulder of the hill adjacent to Alcaria Longa was purposefully located in an area where topography and bedrock outcrops made plowing impractical. It appeared to be particularly stable compared to the rest of the slope. As expected, it yielded the deepest hillslope soil (approximately $33 \mathrm{~cm}$ ). Artifacts in contact with bedrock, however, show that this area also was stripped of sediments in the past, during or after the Medieval Islamic period. The soil therefore indicates the degree of development that can be expected in hillslope sediments in areas that have been stable since the Medieval Islamic period.

The sediments exposed at the foot and toe of both slopes show that these locations were not stripped in the past. Soil formation in the basal deposits suggests that they correspond to a period of landscape stability. The occurrence of artifacts only at and above the upper boundary of these units shows that landscape stability antedated the Medieval Islamic period occupation. The strata above these appear to have been deposited rapidly. Inclusion of artifacts shows that these sediments were deposited during or after the Islamic period, most likely due to erosion of the upper portions of the slopes. The physical characteristics of the immediately superjacent strata reflect soil formation and, therefore, a protracted period of landscape stability. Finally, the uppermost $\sim 35 \mathrm{~cm}$ of deposits correspond to the current hillslope soils, although they exhibit slightly 


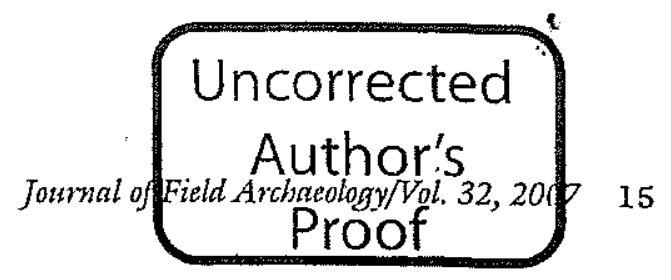

stronger soil development due to geomorphic position and inherited characteristics; these surface deposits have probably been accumulating at the base of the hillslope due to erosion during the past few decades. In general, the soil stratigraphic profiles reflect two episodes of deposition, corresponding with erosion of the upper portions of the hillslopes, as well as periods of relative landscape stability before and between the erosional events.

\section{Discussion of Geoarchaeological Studies}

To summarize, the fluvial study units reflect widespread erosion in the past, followed by a protracted period of relative landscape stability, and then by renewed hillslope erosion and floodplain deposition. Each of the fluvial units includes a stone line indicative of hillslope erosion and channel formation in the past. In every case where Medieval Islamic period artifacts were present they were associated with these strata, and charcoal recovered from one such stratum was dated to the later Medieval Islamic period. Below the stone lines, we consistently encountered unaltered parent material or bedrock, and there is therefore no preserved evidence for significant erosional events before the Medieval period in the loci we investigated. Above the stone lines, and chronologically after the Medieval Islamic period, strata in each profile indicate a period of landscape stability and soil development; these probably correspond to the period of depopulation from the late 12th through the 14 th centuries A.D. Finally, the strata at the top of each profile record the widespread hillslope erosion and floodplain deposition caused by changes in land use during the 20th century.

Our studies of hillslope deposits near the sites of Queimada and Alcaria Longa corroborate the history of landscape change deduced from investigations in fluvial contexts. Prior to increases in population density in the area, the landscape was apparently stable for an extended period of time, allowing soil development on the hillslopes and in the now-buried deposits at the bases of the slopes. This period of stability was followed by an episode of extreme erosion that stripped virtually all loose sediments from the hillslopes. The stratigraphic position of artifacts shows that the erosion is correlated with the Medieval Islamic occupation. Following the Medieval Islamic period, conditions again favored landscape stability. Bedrock weathering with aeolian inputs led to the buildup of sediments on hillslopes and the formation of soils in these sediments. Finally, both of the studied slopes are currently experiencing at least a moderate amount of erosion, most likely related to plowing for cultivation of cereal crops.

Studies of the hillslope soils also provide for a more secure and complete interpretation of the fluvial stratigraphy.
Specifically, it appears as thaugh downcutting of the ephemeral stream systems in the study area corresponds to stripping of soils from adjacent slopes and the resulting increase in runoff. As has been documented in many arid environments (e.g., Yair 1994), erosion of slope sediments initially creates pockets of deep and well-watered soil at the bases of slopes, but increased runoff eventually causes ephemeral streams to incise. The incised streams effectively transport both water and sediment to trunk streams, significantly reducing agricultural potential. This, we argue, was the case in the study area by the mid-12th century A.D.

The combined evidence from fluvial and hillslope contexts supports the contention that human activity has been the primary cause of erosion in the study area, at least during the Medieval and Modern periods. In both contexts, strata indicative of erosion are consistently associated with artifacts. In addition, linking the behavior of stream systems to the movement of sediments and water on hillslopes provides strong evidence that the formation of incised channels in the past was due to landscape change and not to the complex behavior of the fluvial systems themselves. Given the evidence for dense settlement during the $\mathrm{Me}$ dieval Islamic period, it is reasonable to infer that the landscape change was anthropogenic. The ensuing abandonment of rural sites prior to the Reconquista suggests a recursive relationship in which human land-use had substantially altered the local environment and ecology, in turn creating significant constraints on subsistence practices.

\section{Conclusions}

The pattern of rural development in the Lower Alentejo during the transition from antiquity to the Medieval and Modern periods shows both broad similarities and contrasts with other areas of continental Europe during this time. With the withdrawal of Roman military protection in the first decade or two of the 5th century A.D., small villas and Roman farmsteads appear to have been abandoned. In the early 7 th century, small rural hamlets begin to appear in the survey area, followed by a period of sustained, and probably accelerating, growth. Although the influx of Arab or Berber populations after the Muslim invasions of A.D. 711 may have been a part of, or even the cause, of this growth, there is no compelling material evidence for this one way or the other until the late 10th century, and the period between the 7 th and 10th centuries appears to be of one piece from the perspective of settlement pattern and material culture.

Following this period of growth, there is wholesale reorganization of the settlement pattern into aggregated hilltop villages during the mid- to late-10th century A.D. It is at this point that the first clear signs of Islamization, or at 
least, Arabization, begin to appear in the archacological record in the form of glazed Islamic-style food serving wares, Islamic glass, silver jewelry, and Arabic inscriptions. Thus, the most salient transformations in settlement pattern and material culture coincide with the consolidation of the Ummayad Caliphate in Córdoba in the mid-10th century, and not the Arab and Berber invasions of A.D. 711 .

Although the rural economy was based on the same set of resources as the Roman and Medieval Christian economies, increased rural population densities during the Medieval Islamic period eventually led to environmental degradation. Soil erosion throughout much of the study area, probably caused by widespread cultivation on hillslopes, initially created pockets of deep, well-watered soils at the bases of denuded slopes. This initial phase of landscape change may, in part, explain the aggregation of rural populations into larger villages located near these loci of high agricultural potential at about A.D. 1000. Subsequently, populations continued to grow, human impacts appear to have increased, and continued erosion from hillslopes eventually created conditions that favored the formation of incised channels along ephemeral stream systems. These channels effectively transported both water and sediments to trunk streams and thus negatively impacted the agricultural potential of land throughout the study area. Charcoal from within one of these channels was radiocarbon dated to the mid-12th century, suggesting that this process was at least well underway by then. At the same time, rural settlements were abandoned, as much as a century before the Christian Portugues captured the area. Degradation of the landscape appears to have significantly impacted settlement patterns and demography. Ultimately, the agrarian economy collapsed, rural populations were forced to move elsewhere, and the Christians conquered a degraded landscape that remained significantly depopulated for the next two centuries.

\section{Acknowledgments}

We thank Cláudio Torres, Santiago Macias, Susana Gomez, Virgilio Lopes, Miguel Rego and members of the Campo Arqueológico de Mértola for their advice, support, and hospitality. Boone thanks Elizabeth Dinsmore for her considerable contribution to this project from 1993 to 1996, and Camille Sayer, Garnett McMillan, and Mark Emerson, who assisted in the 1992 survey. This research was supported by NSF grants AGS-Archaeology \#0412864 and BNS-8907585, the Earthwatch Corp., the Wenner-Gren Foundation, the Luso-American Development Foundation, the University of New Mexico Research Allocations Fund, and the Latin American and Iberian Institute at the University of New Mexico.
James L. Boone (Ph.D. 1980, SUNY-Binghamton) is Associate Professor of Anthropology at University of New Mexico. Mailing address: Anthropology Department, University of Nevv Mexico, Albuquerque, NM 87131. E-mail:

jboone@unm.edu

F. Scott Worman is a Ph.D. candidate in Anthropology at University of New Mexico. E-mail: fscott@unm.edu

Alarcáo, Jorge

1988 O Dominio Romano em Portugal. Mem Martins, Portugal: Publicaçôes Europa-Americana.

Amorim Ferreira, $\mathrm{H}$.

1970 O Clima de Portugal. Lisbon: Scrviço Meteorológico Nacional.

Antunes, Miguel Telles

1996 Alimentacão de origem animal em regime islâmico-Alcaria Longa e Casa II da Alcaçova de Mértola. Argfueologis Medieval 4: 267-276.

Antuncs, Migucl Telles, and Adel Sidarus

1993 "Mais um quirate cunhado cm Beja em nome de Ibn Qasi e Abu Talib al-Zuhri," Arguseologia Medieval 2: 221-224.

Argemi Relat, Mercè, Jaume Oliver Bruy, and Glòria Soler Chic

1993 "Alcaria Ruiva (Alentcjo): un assentament rural entre dues formacions socio-cconòmiques," in Antonio Mira-Perceval Pastor and Antonio Amorós Sánchez, cds., IV Congreso do Arqueología Medioval Esprañola Vol. 2. Alicante: Asociacion Española de Arqueología Medieval, 435-442.

Bahre, Conrad J.

1991 A Legacy of Change: Historical Human Impact on Vegetation in the Arizona Borderlands. Tucson: University of Arizona Press.

Ballais, Jean-Louis

2000 "Conquest and Land Degradation in the Eastern Maghreb During Classical Antiquity and the Middle Ages," in Graeme Barker and David Gilbertson, eds., The Archneolosy of Drylands: Living at the Margin. London: Routledge, 125-136.

Barros, Maria de Fatima Rombouts, Joaquim Ferreira Boiça, and Celeste Gabriel

1996 As comendas de Mértola e Alaria Ruiva. As visitafocs os tombos da Orden de Santiago, 1482-1607. Mértola: Campo Arqueológico de Mértola.

Bazzana, André, Patrice Cressier, and Pierre Guichard

1988 Les Châtenux Ruraux d'Al-Andalus: Histoire et Archélogie des Husun du Sud-est de l'Espagne. Madrid: Casa de Velásquez.

Bintliff, John L.

1992 "Erosion in the Mediterranean Lands: A Reconsideration of Pattern, Process and Methodology", in Martin Bell and John Boardman, eds., Past and Present Soil Erosion: Archneological and Geographical Perspectives. Oxbow Monograph 22. Oxford: Oxbow Books, 125-132.

Birkcland, Peter $W$.

1999 Soils and Geomorphology. New York: Oxford University Press.

Boone, James L.

1993 "The Third Scason of Excavations at Alcaria Longa" Arquelogia Medicial 2: $111-152$. 


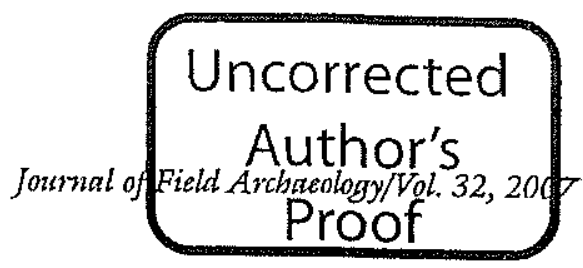

1994 "Rural Settlement and Islamization: The Evidence from Alcaria Longa," in Juan M. Campos, J. Aurclio Perez, and Francisco Gomez, eds., Arqueologia en el Etorno del Bajo Guadiana: Actas del Encuentro de Arqueologia del Suroeste. Huclva: Universidad de Huelva, 527-544.

1995 "Uma Socicdade Tribal no Baixo Alentejo Medicval?" Ar. queologia Medicoal 4: 25-35.

2002 "Tribalism, Ethnicity, and Islamization in the Baixo Alentejo of Portugal: Preliminary Results of Investigation into Transitional Period (A.D. 550-850) Rural Settlements," Em Argueologia 4: 104-121.

Bryan, Kirk

1940 "Erosion of the Valleys of the Southwest," New Mexico Quarterly Reviav 10: 227-232.

1942 "Pre-Columbian Agriculture in the Southwest as Conditioned by Periods of Alluviation," Proceedings of the Eighth American Scientific Congress, May 10-18, 1940: 57-74.

Bull, William B.

1991 Geomorphic Responses to Climatic Change. New York: Oxford University Press.

1997 "Discontinuous Ephemeral Streams," Geomorphology 19: 227-276.

Buol, Stanley W., Francis D. Holc, Ralph J. McKracken, and Randa J. Southard

1997 Soil Genesis and Classification. Ames: Iowa State University Press.

Butzer, Karl

1996 "Ecology in the Long View: Settlement, Agrosystem Strategies, and Ecological Performance," Jostmal of Field Archaeology 23: 141-150.

Chester, David. K., and Peter A. James

1991 "Holocene Alluviation in the Algarve, Southern Portugal: The Case for an Anthropogenic Cause," Joumal of Archaeological Science 18: 73-87.

1999 "Late Pleistocene and Holocene Landscape Development in the Algarve Region, Southern Portugal," Journal of Meditemanean Archaeology 12: 169-196.

Cooke, Ronald U., and Richard W. Recves

1976 Arroyos and Environmental Change in the American Southwest. Oxford: Clarendon Press.

Collaço, Joäo Tello de Magalhăes

1931 Cadastro da Populafẵo do Reino (1527). Lisbon: Emprêsa Nacional de Publicidades.

Glick, Thomas F.

1995 From Muslim Fortress to Christion Castle: Social and Cultural Change in Medieval Spain. Mancester: Manchester University Press.

Hall, Steven A.

1980 "Channel Trenching and Climatic Change in the Southern Great Plains," Geology 18: 342-345.

Harden, Jennifer, and Emily M. Taylor

1983 "A Quantitative Comparison of Soil Development in Four Climatic Regimes," Quatumary Resenrch 20; 342-359.

Hereford, Richard

1984 "Climate and Ephemeral-Stream Processes: Twenticth Century Geomorphology and Alluvial Stratigraphy of the Little Colorado River, Arizona," Geological Society of America Bulletin 95: 654-668.
Hodges, Richard

2003 Villa to Village: The Transformation of the Roman Countryside in Italy: C. 400-1000. London: Duckworth.

Huckleberry, Gary

2001 "Archaeological Sediments in Dryland Alluvial Environments," in Julie K. Stcin and William R. Farrand, eds., Sediments in Archaeological Context. Salt Lake City: The University of Utah Press, 67-92.

Lcopold, Lunà B.

1976 "Reversal of Erosion Cycle and Climatic Change." Qzaaternary Research 6: 557-562.

Lopes, Virgilio

2003 Mértola na Antiguidade Tardia: A topografia bistórica da cidade e do seu território nos alvores do cristianismo. Porto: Gráfica Maiadouro.

McFadden, Leslie, and Joseph McAuliffe

1997 "Lithologically Influenced Geomorphic Responses to Holocene Climatic Changes in the Southern Colorado Plateau, Arizona: A Soil-Geomorphic and Ecologic Per. spective," Geomorphology 19: 303-332.

Macias, Santiago

1993 "Um Espacio Funerario," in Cláudio Torres and Santiago Macias, eds., Basilica Paleocristã. Mertola: Campo Arqueológico de Mertola, 30-57.

McMillan, Garnett, and James L. Boone

1999 "Population History and The Islamization of the Iberian Peninsula: Skeletal Evidence from the Lower Alentejo, Portugal," Current Antbropology 40: 719-726.

Patton, Peter $\mathrm{C}_{\text {, }}$ and Stanley A. Schumm

1981 "Ephemeral-Stream Processes: Implications for Studics of Quaternary Valley Fills," Quatemary Research 15: 24-43.

Popc, Kevin O., and Tjeerd H. van Andel

1984 "Late Quaternary Alluviation and Soil Formation in the Southern Argolid," Joumial of Archneological Science 11: 28I-306.

Potter, Timothey W.

1976 "Valleys and Sediment: Some New Evidence," World Ar chaenlogy 8: 207-219.

Ritter, Dale F., R. Craig Kochel, and Jerry R. Miller

1995 Process Geomorphology (third edn). Boston: WCB McGrawHill.

Santos, Rui

1987 O Socom o dos Lavradores de Mértola em 1792. Mértola: Canpo Arqueológico de Mćrtola.

Schumm, Stanley A., and R. S. Parker

1973 "Implications of Complex Response of Drainage Systems for Quatcrnary Alluvial Stratigraphy," Nature 243: 99-100.

Serviço de Ronconhecimento e Ordenamento Agrario, Secretaria de Estado da Agricultura

1961 Carta dos Solos de Portugal, 46-C. Lisbon: Litografia de Por tugal.

1962 Carta da Capacidade de Uso do Solo, 46-C. Lisbon Litografia de Portugal.

Soil Survey Staff

1975 Soil Taxonomy. U.S. Department of Agriculture Handbook No. 436. Washington, D.C.: U.S. Government Printing Office. 
1993 Soil Survey Manual. U.S. Department of Agriculture Handbook No. 18. Washington, D.C.: U.S. Government Printing Office.

Stevenson, A. C., and Richard J. Harrison

1992 "Ancient Forest in Spain: A Model for Land-use and Dry Forest Management in South-west Spain from 4000 B.C. to 1900 A.D.," Procedings of the Prelsistoric Society 58: 227-247.

Stuiver, Minze, and Reimcr, Paula J.

1993 "Extended 14C Database and Revised CALIB Radiocarbon Calibration Program. Radiocarbon 35: 215-230.

Thornes, John B.

1987 "The Palaeo-ccology of Erosion," in J. Malcolm Wagstaff, ed., Landscape and Culture: Geographical and Archaeological Perspectives. Ncw York: Basil Blackwell, 38-57.

Thornes, John B., and Antonio Gilman

1983 "Potential and Actual Erosion Around Archacological Sitcs in South East Spain," Catena Supplement 4: 91-113.

Tillery, Anne, Peter Fawcett, Leslie McFadden, Louis Scuderi, and Joseph McAuliffe

2003 "Late Holocene Bchavior of Small Drainage Basins on the Colorado Plateau: Influences of Lithology, Basin Form, and Climate Change," in Spencer G. Lucas, Steven C. Semken, William R. Berglof, and Dana S. Ulmer-Scholle, eds., Geology of the Zuni Platenu: Nev Maxico Geological Society, Fifty-fourth Annual Field Conference. Socorro: New Mexico Geological Socicty, 197-208.

Toubert, Pierre

1990 Castillos, señores, y campesinos on la Italia medieval. Barcelona: Editorial Crítica

van Andel, Tjeerd H., and Curtis Runnels

1986 "Five Thousand Years of Land Use and Abuse in the South. ern Argolid, Grecce," Hesperia 55: 103-128.

van Andel, Tjeerd H., Eberhard Zangger, and Anne Dernitrack

1990 "Land Use and Soil Erosion in Prehistoric and Historical Greece," Joumal of Field Archaeology 17: 379-396.

Van der Leeuw, Sander

2000 "Drylands Present and Past: Searching for the Causes and Consequences of Desertification, Land Degradation and Land Abandonment on the Northern Mediterranean Shores," in Gracme Barker and D. D. Gilbertson, eds., The Archaeology of Drylands: Living on the Margins. London: Routledge, 336-353.

Vita-Finzi, Claudio

1976 "Diachronism in Old World alluvial sequences," Nature 263: 218-219.

Wainwright, John

1994 "Anthropogenic Factors in the Degradation of Semi-arid Regions: A Prehistoric Case Study in Southern France," in A. C. Millington and Kenneth Pye, eds. Environmental Change in Drylands: Biogeographical and Geomorphological Perspectives. New York: John Wilcy and Sons, 285-304.

Yair, Aaron

1994 "The Ambiguous Impact of Climate Change at a Desert Fringe: Northern Negev, Isracl," in A. C. Millington and Kenueth Pyc, eds, Environmental Cornge in Drylnnds: Biogeograplical Perspectives. New York: John Wilcy and Sons, 199-228. 